\title{
A 'virus-free' cell line derived from a patient with infectious mononucleosis
}

\author{
S. D. MARSTON, E. J. P. AlMOND, N. P. BISHUN, E. D. MAUnSEll, AND \\ R. N.P. SUTTON
}

From the Department of Medical Microbiology, King's College Hospital Medical School, London, St Giles' Hospital, London, and the Research Department, Marie Curit Memorial Foundation, Oxted, Surrey

SYNOPSIS A continuous cell culture line, derived from a nurse with infectious mononucleosis, is described. Electron microscopic and immunofluorescent examination suggested that it was substantially free from detectable complete virus particles, although the presence of a soluble complement-fixing antigen showed the persistence of other antigenic components of the EB virus.

During the past decade, many cell lines have been derived from Burkitt tumour biopsies and from peripheral blood drawn from normal individuals and from patients with a variety of conditions (Epstein and Barr, 1964; Moore, Gerner, and Franklin, 1967; Moore, Ito, Ulrich, and Sandberg, 1966; Diehl, Henle, Henle, and Kohn, 1968). Many of these cell lines harbour herpes-like viruses; some do not, and these have shown themselves of special value in the detection of those antigens which are formed in the early stages of the EB virus replicative cycle (see Klein, 1971, for a review of this subject). In the following report, we describe the development and characterization of a further cell line derived from a patient with infectious mononucleosis which is, we believe, substantially 'virus-free'.

The patient was a student nurse of 20 years (R.M.) who was admitted on 6 September 1970 with two weeks' history of fever, sore throat, and posterior cervical lymphadenopathy; over the next four days the lymphadenopathy increased to involve the axillary nodes and the spleen became palpable. During the next two weeks, with the exception of an episode of arthralgia of the small joints of both hands on 22 September her condition gradually improved and she was discharged on 29 September. Films of peripheral blood, taken on 6, 9, and 15 September showed an increasing $(17,22$, and $30 \%)$ proportion of the typical abnormal lymphocytes of infectious mononucleosis. Monospot tests performed on 7 and 14 September were positive, as was a differential Paul-Bunnell test on 15 September. Her serum had reverted to normal by 16 November.

Received for publication 4 May 1972.
A specimen of peripheral blood was taken on 18 September, the leucocytes were separated by the method of Diehl, Henle, Henle, and Kohn (1968) and cultured in Eagle's Minimal Essential Medium with foetal calf serum $(20 \%), 200 \mathrm{mM}$ glutamine $(1 \%)$, non-essential amino acids ( $1 \%$ ), and added penicillin and streptomycin. This cell line has now been cultured for 10 months and grows with some difficulty in RPMI 1640 medium with $20 \%$ foetal calf serum and added antibiotics. The cell doubling time has varied from 4.1 to 10.3 days but is currently 6.0 days and the highest viable or total cell count attained is about $50 \times 10^{4}$ cells $/ \mathrm{ml}$. Cytochemical tests (Sudan Black, PAS acid phosphatase) on cells taken after two months in culture gave very similar results to those found in fresh preparations from patients with infectious mononucleosis. Chromosome preparations of cell samples taken after about six months in culture showed a normal female karyotype with no structural or numerical chromosomal aberrations; chromosomal breaks and gaps were within the range normally observed in cells which are not known to be infected with viruses. At the time that this culture was examined, the only other similar cell line held in the laboratory was the EB3 line, which was derived from a male.

Samples of cells taken after 13 weeks in culture were fixed in epon, embedded in Araldite, sectioned, and examined under an AEI EM6B electron microscope. Morphologically, the R.M. cells resembled the EB3 cells but no herpes-like, or other, virus particles were seen after prolonged searching, although these were easily seen (see Fig. 1.) in cell samples taken from EB3 cultures and processed in exactly the same way. Cell smears of R.M. and 


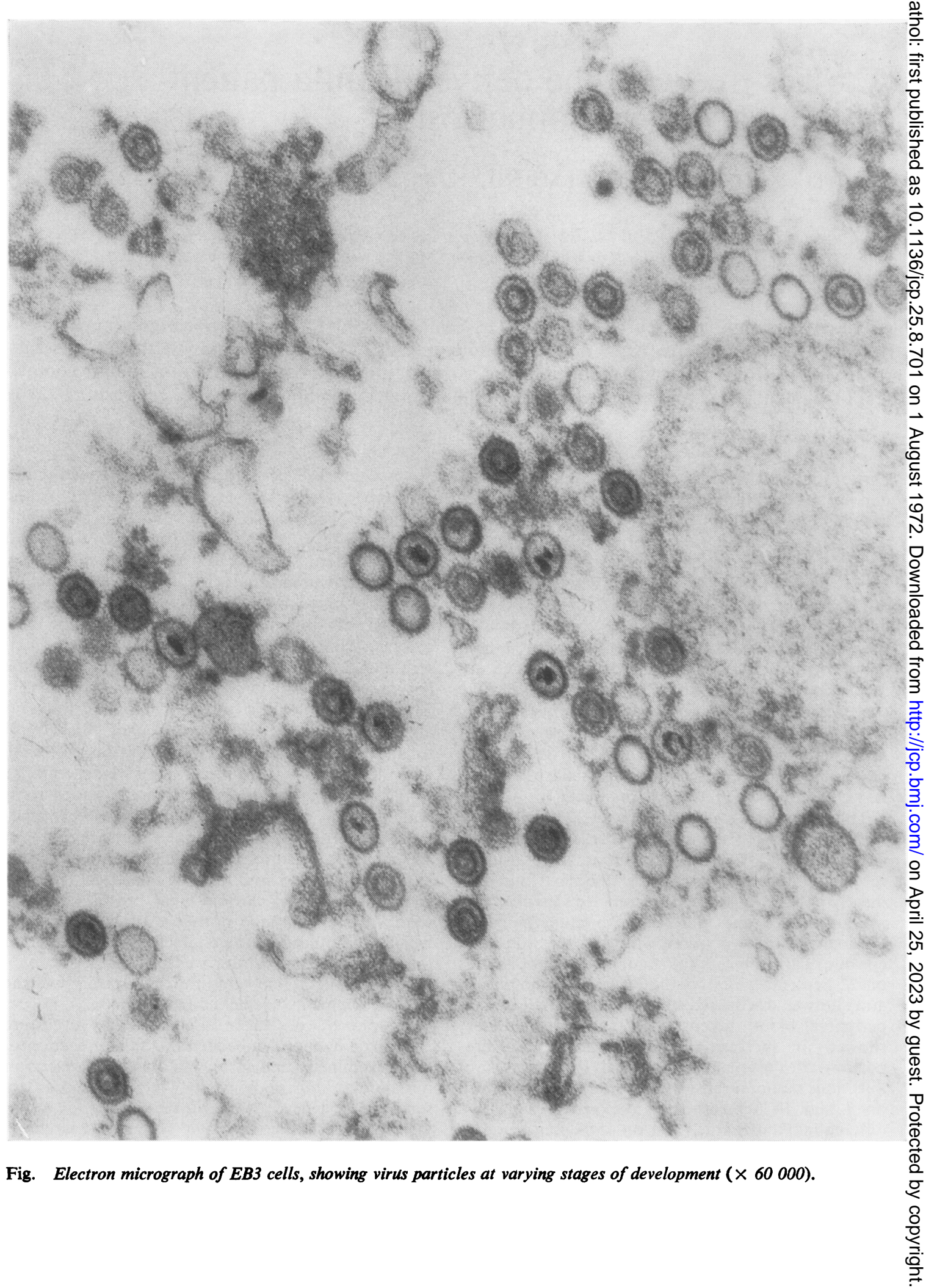




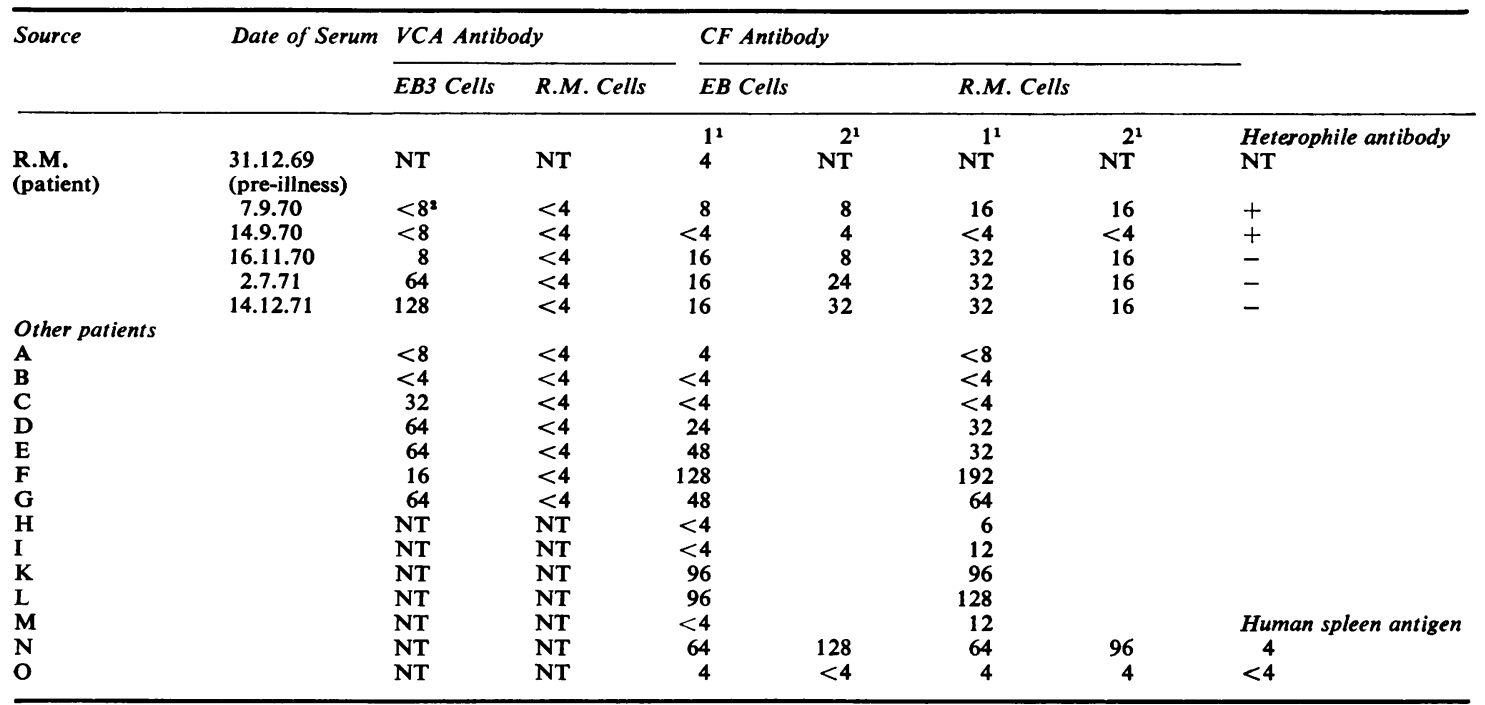

Table Antibodies to virus capsid and soluble complement-fixing antigens in EB3 and R.M. cells

${ }^{1}$ Replicate tests with different batches of antigens.

${ }^{2}$ Reciprocal titres.

Significance of differences between EB and R.M. complement-fixing antibody levels estimated by Wilcoxon matched-pairs signed-ranks test. $\mathrm{N}=18 \mathrm{t}=47 \cdot 5$, not significant at $5 \%$ level in a two-tailed test.

EB3 cells were fixed in acetone and examined for the presence of virus capsid antigen in an indirect fluorescent antibody test (Henle and Henle, 1966). No fluorescence was ever observed when sera from a variety of sources were tested with the R.M. cells although many of these reacted strongly with the EB3 cells. A soluble complement-fixing antigen was prepared from the R.M. cells by a method described elsewhere (Sutton, Marston, and Emond, 1971). Sera from our patient and from other patients and control individuals were tested against three batches of R.M. antigen and against three batches of antigen prepared from EB3 cells and a control antigen prepared from foetal human spleen. These results are detailed in Table I. They show a close concordance in the results of the complement-fixation tests but an absolute discordance in the immunofluorescent tests. This suggests that the complementfixing antigens prepared from both lines of cells are antigenically closely related, if not identical.

The failure to demonstrate virus particles by electron microscopy is, of course, no proof that they are not there, although it is reasonable to assume that, if present at all, they are fewer than in the EB3 cells. The failure to demonstrate virus capsid antigen by immunofluorescence lends support to the assumption that the R.M. cells are 'virus-free' as, perhaps, does the difficulty with which these cells grow.
We have now some evidence that the R.M. cells, if not absolutely 'virus-free' at least have a much lower content of visible virus particles than the EB3 cells. Soluble complement-fixing antigens prepared from both cell lines give concordant results whilst immunofluorescent tests (for antibody directed against the virus capsid antigen) differ markedly. This suggests that the R.M. and EB3 soluble complement-fixing antigens are not associated with the virus capsid and that they probably resemble the soluble antigens of Vonka, Benyesh-Melnick, and McCombs (1970) which, it has been speculated, may resemble the $T$ antigens observed in experimental infections with oncogenic DNA viruses.

The presence or absence of virus capsid antigen in cultured cell lines deserves comment. Diehl, Henle, Henle, and Kohn (1968) observed that virus capsid antigen disappeared from cultured infectious mononucleosis cells after about two or three months, although individuals who had recovered from infectious mononucleosis as long as 20 years previously yielded cells with easily demonstrable virus capsid antigen. Henle and Henle (1968) alluded to several reports where the same had occurred under conditions which were optimal for cellular growth. It is apparent that more primitive antigens persist after the disappearance of virus capsid antigen; zur Hausen and von Schulte-Holthausen (1970) have shown EB virus DNA in the 'virus-free' 
RAJI cells, and Pope, Horne, and Wetters (1969) have observed complement-fixing antigens in RAJI cells. The conditions under which virus capsid antigen is cleared from cells are not clear and may be exogenous, eg, unsuitable media, or may be intrinsic qualities of the host cell. It may well be that cells from patients with infectious mononucleosis clear themselves of virus capsid antigen more effectively than those from patients with Burkitt's tumour: if this were so, it would be a subtle and potentially very interesting difference between patients who develop these conditions.

We are grateful to Professor W. M. Davidson (King's College Hospital Medical School) for haematological investigations on our patient; to Professor F. G. J. Hayhoe (Cambridge) for carrying out the cytochemical tests on our cultured cells; to Professor M. A. Epstein (Bristol) for very considerable help and advice in establishing our electron microscope techniques and to Professor W. Henle (Philadelphia) for helpful comments. We are also grateful to Mr C. K. Campbell (Ortho Diagnostics, High Wycombe) for a generous gift of Monospot reagents.
References

Diehl, V., Henle, G., Henle, W., and Kohn, G. (1968). Demonstration of a herpes group virus in cultures of peripheral leucocytes from patients with infectious mononucleosis. J. Virol., 2 , 663-669.

Epstein, M. A., and Barr, Y. M. (1964). Cultivation in vitro of human lymphoblasts from Burkitt's malignant lymphoma. Lancet, 1, 252-253.

zur Hausen, H., and Schulte-Holthausen, H. (1970). Presence of EB virus nucleic acid homology in a 'virus-free' line of Burkitt tumour cells. Nature (Lond.), 227, 245-248.

Henle, G., and Henle, W. (1966). Immunofluorescence in cells derived from Burkitt's lymphoma. J. Bact., 91, 1248-1256.

Henle, W., and Henle, G. (1968). Present status of the herpes-group virus associated with cultures of the hematopoietic system. In Virus-Induced Immunopathology. Perspectives in Virology, VI. New York and London.

Klein, E. (1971). Immunological aspects of Burkitt's lymphoma. In Advanc. Immunol., 1971.

Moore, G. E., Gerner, R. E., and Franklin, H. A. (1967). Culture of normal human leukocytes. J. Amer. med. Ass., 199, 519-524.

Moore, G. E., Ito, E., Ulrich, K., and Sandberg, A. A. (1966). Culture of human leukemia cells. Cancer (Philad.), 19, 713-723.

Pope, J. H., Horne, M. K., and Wetters, E. J. (1969), Significance of a complement fixing antigen associated with herpes-like virus and detected in the Raji cell line Nature. (Lond.) 222, 186-187.

Sutton, R. N. P., Marston, S. D., and Emond, R. T. D. (1971). Some observations on complement-fixing antibodies to the EB virus. J. clin. Path., 24, 801-804.

Vonka, V., Benyesh-Melnick, M., and McCombs, R. M. (1970). Antibodies in human sera to soluble and viral antigens found in Burkitt lymphoma and other lymphoblastoid cell lines. J. nat. Cancer Inst., 44, 865-872. 